\title{
Learning from Giants. Early exposure to advance markets in the growth and internationalization of Spanish health care corporations in the 20th century
}

\author{
Abstract \\ This article examines the influence of early exposure to advanced markets of the \\ United States and Germany in the growth and internationalization of healthcare firms \\ from Spain, a late industrialized country. Based on the case studies of the Spanish \\ corporations Grifols and Ferrer, the study shows that early exposure to advanced markets \\ helped them grow in their national markets, and in the world healthcare industry. It shows \\ further that the specific capabilities developed by both firms were determined by path- \\ dependent networks with scientists and institutions, on the one hand; and strategic \\ alliances, acquisitions and mergers with German and US corporations.
}




\section{Introduction}

The successful development of American multinationals, the globalization of old European groups after World War II, and the oligopolistic structure of the healthcare industry have influenced our perception of this industry in general and the growth and internationalization of the first movers in particular. ${ }^{1}$ According to Alfred D. Chandler Jr, a relatively small number of first movers in the most developed countries defined one century ago the evolving pathways of learning in the pharmaceutical industry, creating: barriers to entry, strategic boundaries, and limits to growth. The barriers set by first movers would have been so high that according to Chandler after the 1920s, in the group of the thirty largest pharmaceutical companies he identified in the most developed markets, no new pharmaceutical enterprise was able successfully to enter their industry (Chandler 2005, 9). The first movers grew in scale and scope, and their size and their control of new learning bases in the industry would, therefore, have made them dominate for a century global health care markets, and would have contributed to prevent that new challengers, and new scientific findings, could change the bases of the industry. ${ }^{2}$

Small players from late industrialized countries, would have therefore face huge disadvantages that may have hampered their opportunities to challenge the supremacy of traditional global leaders from the most developed markets. And yet, there are some examples of firms from these countries that, somehow, have been able to thrive in this environment, climbing to leadership positions in this industry. Obviously, the rise of global leaders from emerging and middle income countries is not a phenomenon

exclusive to healthcare, but to all industries. ${ }^{3}$ However, the huge path dependent differences in capabilities for growth and internationalization in healthcare as compared to other industries, as suggested in studies about the pharmaceutical industry (Chandler 
2005), make the study of the mechanisms of entry of small players from latecomer markets is field extremely interesting. This article wants to be a contribution to the scarce literature that exists, in the business history research field, about the process through which a small company from the periphery can become a global leader. ${ }^{4}$ Our research sheds new light on the growth and globalization of small players in the health care industries born in late industrialized countries, asking how small companies in this environment, with weak or unstable institutional support, have been able to enter the major league of the health care industries, and scale positions to the top levels. Our hypothesis is that, in the healthcare industries, early exposure to advanced markets, and alliances with first movers, may provide these firms with capabilities to grow and be able to cross entry barriers in developed markets. We use in-depth case studies to test this hypothesis and provide arguments which future research may confirm.

More specifically, we propose a comparative exercise in which we examine the long term transformation of two small Spanish companies into such global players: Grifols and Ferrer. Both companies were selected because they operate in different branches of the healthcare industries, but in a similar environment, in order to test the hypothesis. Whereas-Grifols (founded in 1910/1940) ranks third among the top corporations in the world plasma industry, and Ferrer (founded in 1925/1953) is a middle sized pharmaceutical company ( $5^{\text {th }}$ in Spain and 65th in Europe) The plasma industry's key asset is the ownership of high quality raw material and manufacturing and distribution processes, whereas the pharmaceutical industry's key asset is the ownership of brands, licenses, and patents of a vast portfolio of products and processes. The analysis of their growth and internationalization strategies in the second half of the twentieth century in this article concludes that despite the differences their early exposure to North American and German first movers in their respective industries was essential to help small firms 
achieve scale and scope, develop their own learning bases, innovate, diversify their financial bases, and be able to enter global health care markets. The empirical analysis of this process has revealed, moreover, that the main stages of this evolution follows the chronology suggested by Chandler for the first movers of the pharmaceutical and chemical industries in Western Europe and the United States. Between the late nineteenth century and early 1920s core firms created their integrated learning bases in production and marketing; during the interwar years and World War II companies strengthened their capabilities and grew in parallel with the "therapeutic revolution" and the cascade of discoveries linked to penicillin, sulfa drugs, and other health care products developed in war times. In the 1960s and 1970s first movers concentrated in their core businesses to expand production and sales at home and a broad becoming global enterprises, and setting entry barriers to challengers to their industries and markets. After the 1970s new biological and medical findings and new manageurial approaches would have created a new wave of new start ups building up their learning basis and entry barriers (Chandler 2005).

Over the last four decades accelerated growth and globalization have shaped the healthcare industries in Europe, the United States, and Japan. ${ }^{5}$ At the same time, tTheir technological and scientific innovations have contributed significantly to improve life expectancy and reduce inequality in well-being worldwide. ${ }^{6}$ In line with this global growth, pharmaceutical firms from Spain have increased progressively the number of their international operations since the late $1980 \mathrm{~s}^{7}$. An interesting feature of latecomer multinationals, a label for which Spanish MNEs qualify, is that the most dynamic ones usually follow a dual path in their international expansion. On the one hand, they expand into more developed countries with the aim of upgrading their capabilities and catch up with their more advanced competitors. On the other hand, they look for less developed 
countries to exploit their experience and intangible assets. For the last three decades that, for pharma companies, entering into an advanced country is associated to being a most active player in the international arena than those not entering into these countries. ${ }^{8}$ Not only firms investing in advanced countries had undertaken more international operations; they had also a higher propensity to expand aggressively (i.e. without partners) than the firms not entering into these countries.

This article provides a long-term analysis to demonstrate the influence that early imprinting from leaders of advanced economies have had in the growth and international expansion of two small labs of Spain. The article argues that networks and alliances with health care leaders of pioneering German and US corporations encouraged early imprinting of strategic resources needed to grow and be a global firm: scientific, organizational, and market knowledge.

The evidences of this article indicate that this was not a straightforward process, and that there were many difficulties within the firms, and in the relationship of the firms with the external institutional environment and their competitors. The history of the international expansion of Grifols and Ferrer in advanced markets shows that it was preceded by a decades-long process of networking, technology transfer and capability building. This process would allow both firms to use the opportmities provided by globalization and to overcome entry barriers in healtheare markets of developed economies.

In the following sections we first provide a synthetic view about the long term evolution of the Spanish healthcare industries, within the historical framework proposed by Alfred D. Chandler. ${ }^{9}$ Then, we examine the processes of imprinting and internationalization of Grifols and Ferrer in each of the three Chandlerian stages (1880s1920s, 1930s-1980s, 1990-present). Finally, a concluding section summarizes the main 
findings of our comparative exercise.

\section{Dynamics of the Healthcare Industries}

From a technological and institutional perspective, the foundations of the healthcare industries are more than a century old. Chandler identified three big waves of technological and scientific therapeutic revolutions under the lead of a handful of corporations from the United States and Western Europe: the first movers. These waves are briefly characterized in Figure 1. How did firms raised outside the historical core of large and innovative corporations build their capabilities and go international?

Recent studies on the pharmaceutical and biomedical industries in peripheral markets suggest that neutrality during the two world wars and the technological convergence that took place during the golden age accelerated the transfer of old and new scientific and technological innovations to the rest of the world. ${ }^{10}$ Figure 2 reveals that in Spain small firms exposed since the late $19^{\text {th }}$ century to advanced markets were able to develop the learning bases of the new scientific and engineering knowledge by combining resources obtained from local and regional systems of innovation with resources from networks established with first movers from Germany and the United States.

The Spanish health industry borrowed extensively and learnt from the first movers, particularly from the two countries that were leading the second industrialization wave (Germany and US) between the 1880s and 1980s through four major channels: foreign trade; Spanish subsidiaries of, and joint ventures with, foreign MNEs; cooperative environment and US technical assistance. These four channels helped build bridges and networks in both directions.

The connection was first established to import goods and knowledge very scarce 
and expensive to obtain in Spain-during a century, since the end of the $19^{\text {th }}$ century, until the late 1980s. ${ }^{11}$ Changes in the management of the small laboratories in the 1980s transferred through previous channels with leading US and German corporations a new type of knowledge, manageurial and financial knowledge, that helped achieve scale and scope, and the globalization, of both corporations, between the 1980 s and the first years of the 21 rst century. Foreign multinationals did not aim to transfer strategic knowledge that allowed for import substitution strategies of their Spanish partners, but the accumulation of knowledge and networks inevitably provided such knowledge, particularly if the results were profitable to both sides, as it was the case in the history of Grifols and Ferrer. This is the process analysed in the following sections, that follow the Chandlerian chronology of the evolution of modern pharmaceutical and chemical corporations from leading economies.

Early imprinting from first movers of advanced economies. The internationalization of Grifols and Ferrer International

After the end of the Spanish civil war in 1939 the State changed the rules of the game for the health care industries in the country until the late 1970s. The different governments created in those decades: a new mandatory public health insurance for all Spaniards in the early 1940s; new central public agencies to regulate medical and pharmaceutical services and products that increased public social spending (that after the 1950s represented a substantial growth in public health spending with the construction of new large centralized hospitals); regulations fixing the number of new pharmacies that could open in the market; and regulations fixing pharmaceutical prices between 1963 until 1975. This situation represented great incentives for national and foreign pharmaceutical large corporations, and a rapid growth in the demand of hospital supply equipment, that 
until the late 1970s yielded large profits to a few big national producers and to many big foreign US and Western European multinationals. Spain was experimenting the baby boom years and the institutional conditions protected salaried workers and their massive access to health care products and services through public and private insurance companies (Pons and Vilar 2014; Chaqués 1999).

Grifols and Ferrer were two typical small labs that started their family activities in this context. Small firms were in disadvantage in the Spanish health care market. Foreign currency to pay imported raw materials or equipment was not easily available to them, and public bids for the construction or supply of the new large hospitals were often won by a few large companies with privileged connections in Madrid, the center of regulating agencies. their production was different of the strategies of alliance to develop in coming decades. Both were born in Barcelona, in close connection with the scientific and research centers of Medicine and Pharmacy that had traditional networks with leading researchers and centers of Western European countries. They were different, though. Grifols specialized in blood products, and Ferrer in pharmaceutical drugs. Whereas the plasma industry depends on stable and large supplies of high quality raw material, the pharmaceutical industry needs to invest heavily in marketing and patented/licensed innovation. For these reasons, in the last 25 years Grifols has relied on mergers and acquisitions in their internationalization process, far more than Ferrer, which has resorted to strategic alliances in the research and marketing areas.

The resources and skills both companies used to go abroad had a long history of creation, and originated in a similar environment, which fits broadly speaking Chandler's proposed chronology of evolution of modern corporations in other more advanced economies. 


\section{The embeddedness in local systems of innovation in the healthcare industries in}

Barcelona, 1880s-1920s

The Spanish health system experienced remarkable progress in the early decades of the $20^{\text {th }}$ century, laying the foundation of modern public health policy and institutions. ${ }^{12}$ This modernization effort was supported by knowledge originated in the advanced European nations as well as by the International Health Board of the Rockefeller Foundation, among others. ${ }^{13}$ Barcelona was a city where demographic, industrial, and scientific changes had combined to create an advance health care district in Spain between the 1880s and the early 1930s. ${ }^{14}$ In this favorable local context small enterprises in the clinical analysis activity, in the production of pharmaceutical drugs, and in the private surgical activity appeared, led by professionals of the Medicine and the Pharmaceutical local Faculties

flourished. ${ }^{15}$ Our two firms participated in this dynamic environment in different ways. Grifols, in the creation of outward-looking clinical labs (in 1910, 1940) and the first civil Spanish blood bank (1945). Ferrer, in the creation of outward-looking pharmaceutical labs (1925).

Grifols archive preserves newspapers and books with conference papers of the late 1920s and early 1930s and 1940s that show the persistent activity of learning updated news of German, French, Italian, and British scientists in the field of clinical analysis (Grifols Historical Archive in Barcelona. Newspapers section and Library). Josep Antoni Grifols Morera graduated in Medicine from the University of Barcelona in 1889, and his son, José Antonio Grifols Roig, would study Medicine too. Upon his graduation in 1909, he undertook a life changing travel to Danzig and Munich, where he specialized in pathology and lab practice. Back in his home town, he founded a small clinical laboratory 
-Instituto Central de Análisis Clínicos- with Drs. Celis, Moragas and Gordan. In 1925 one of Grifols' German collegues, Dr. Helmut Hempel, who was fleeing inter-war Germany, joined the Barcelona laboratory. In the 1920s, much of the laboratory's work focused on syphilis and other infectious diseases. It did not take long for the third generation, Victor and José Antonio Grifols Lucas, to start helping their father to conduct urine tests and count white blood cells. An example of science-based dynastic family firm.

In contrast, the origins of Ferrer provide an insight into the commercial and industrial atmosphere of Barcel ona Medir, Ferrer y Cía, Ferrer' s forerunner, was founded in $1925 .{ }^{16}$ It was one of the many partnerships established at the time to seize the opportunities of importing drugs from the most advanced countries and serving the growing Spanish urban population. International networking and modern marketing were to play a relevant role in the development of Ferrer International.

In this stage both small labs were run by outward looking entrepreneurs with scientific education, fluent in foreign languages, and with an embedded strategy of keeping a regular knowledge of news from leading centers and companies in their different market niches of clinical analysis, and pharmaceutical drugs over the counter.

New organizational and commercial knowledge from the United States and Germany and growth in scale and scope, 1930s-1990s

In this second stage both labs had to adapt to a cycle of collapse and slow reconstruction and late international integration in their traditional activities in their home markets due to the Spanish Civil War (1936-39), Franco's dictatorship (1940-1975) and the international orientation of the new democratic governments after 1975, which imposed a long period of strict limitations to foreign trade and knowledge transfer, and therefore a common framework of difficulties to 
maintain former links with European firms. After World War II both labs struggled to maintain contacts with European firms and scientific institutes and congresses, and would focus their scarce resources in importing knowledge, and establishing alliances, with firms and centers from the three economies that seemed to be dominating innovation and world markets in the most knowledge intensive products and processes: Germany, the United States, and Japan.

The changing environment, and the new contacts, required organizational changes in both labs, to grow and design new internationalization strategies. In the case of Grifols, during World War II a German Jewish doctor, Dr. Oppenheimer, who had escaped from nazi Germany, came to work to the Grifols laboratory. The German staff continued to help Grifols keeping up to date with the latest discoveries in microbiology and blood testing. The Civil War in Spain (1936-1939) provided the Grifols family with a new learning experience: both Grifols Lucas brothers went to work at Spain's first blood bank, where they learnt to treat and classify donors, preserve and re-use blood and send it to distant locations within the Republican zone. Shortly after the war, in 1940, 55 year old Grifols Roig embarked on the foundation of Laboratorios Grifols with his and his wife's capital. His two sons resumed their studies, graduating in Chemistry and Pharmacy and joining the family lab. In 1946 Victor Grifols Lucas went to England to study penicillin production and visit two of his father's Catalan exiled friends, Dr. Trueta in Oxford and Dr. Duran in Manchester.

Grifols had a new patent, a new market, talented sons, a loyal local and German staff, and long-term capital from local networks. It seemed the right time to find appropriate foreign partners. The Grifols Lucas found it first in Dr. Robert Race of the Lister Institute. Race, who had established the structure of the human chromosome related to the RH system, was invited to Barcelona and he agreed to cooperate with 
Grifols on analysis-related matters. The Grifols sought to enter the specialized market niche of plasma fractionation, which they achieved in 1956. Given Spain's poor international reputation, it was very difficult for Grifols to sell plasma outside the Spanish market. They found a way: selling it under the customer's brand. ${ }^{17}$

For serums and reagents, friendship with a Barcelona pharmacist, Dr. Roca Vinyals, helped connect Laboratorios Grifols with the North American company Dade Reagents in Spain that allowed Grifols to export plasma and import their reagents. Dade's top management, Dr. Griffitts and Mr. Potts suggested incorporating a joint venture company, Dade Grifols, half owned by Dade Reagents, and half owned by the Roca de Vinyals and the Grifols family. The company was one of the most profitable business experiences in the history of Grifols. New products much in demand in the Spanish health system (cardiovascular products and lab equipment particularly), with the new capital and managerial advice contributed by the North American partners, and in-site training in the North American factories opened up a new period in the history of the labs. ${ }^{18}$ Three women would play a very relevant role in launching initiatives that would consolidate the scientific reputation of Dade Grifols: María Cristina Cadira (co-manager of Dade Grifols, sister of Roca de Vinyals's widow), Julia Mas (Director of the immuhemathology lab) and Montserrat Viñals (Chemistry graduate, Technical Director of Dade-Grifols, and wife of Grifols commercial top manager between the 1950s and the 1970s Antonio Ruiz). ${ }^{19}$ It was the beginning of new times, the alliance in 1960 of a small biopharmaceutical company of Barcelona with a North American pioneering giant in the clinical laboratories industries.

The mid 1950s until the early 1980s were therefore decades of fruitful cooperation of the small Grifols lab with two North American partners, first Dade Reagents (1957/1960-1965) and then American Hospital Supply Corporation (1966-1982) that 
allowed growth and conquest of the Spanish market, a strong import activity of US products and managerial practices, and a few (almost symbolic) exports of small quantities of their products to European markets (Germany, and Switzerland in the 50s, Sweden in the 60s) and the United States. ${ }^{20}$ Sales within Europe in the 1950s and 1960s were basically of the same type as they had been within Spain in the late 1940s and early 1950s, maquila style: Grifols sold to other labs with prestigious names (vaccines and penicillin to Sociedad General de Farmacia and gamma globulin to Hubber in Spain, blood to Swiss Red Cross, gamma globulin to the Swedish Kabi), and those labs added their brands on the products before reaching their final client. During the mid 1950s, and particularly after the association with Dade Reagents and with American Hospital Supply Corporation, exports of plasma to the United States followed strict transparent rules which allowed for greater visibility of the Grifols brand and products in the US market, and in the Food and Drugs Administration. This increased indeed sales, and reputation. The friendship of Grifols Lucas with Guillermo Anido, innovation manager in Dade Reagents and in American Hospital Supply Corporation, and the opportunity to send Spanish staff to a US corporation where Spanish speaking Cubans arrived from the exile, and highly qualified in lab techniques and quality control, was a lucky opportunity that allowed Grifols to send their own patents to be considered for exploitation in the US market, and to export plasma to the United States.. ${ }^{21}$

A regulatory change would stop this promising path, and required reinforcing the alliance with the US partner: the Spanish Government prohibited the export of blood, in 1965, and exports sharply declined from 3.3 million Spanish pesetas in 1965 to 917,000 pesetas in 1966. The domestic market had to be the solution to survive, in a compulsory reconquest of Spanish markets, with sales increasing from 875,000 pesetas in 1965 to 2.2 million pesetas in 1966. The US partnership Dade Grifols decisively helped in this 
reconquest, providing new exclusive products for hospital consumption, and training in US manageurial practices typical of a large Chandlerian corporation. Sales and profits account for the great support provided by the joint partnership. Quantitatively speaking, in 1966 the sales (59.2 millons of Spanish pesetas) of this joint partnership with a US corporation were approximately thirty times bigger than the sales of the other two firms of the Grifols group Laboratorios Grifols (2.2 million pesetas) and Gri-Cel (less than 1 million) that very same year. ${ }^{22}$ Profits of Dade Grifols were around three to eight times the average profits of Laboratorios Grifols and Gri-Cel during the first three years of the 1970s, the only ones for which information has been able to be found after the loss of the Dade Grifols archive when they merged with Baxter Travenol in the mid 1980s. ${ }^{23}$

There were a few weaknesses in the years of transformation of the small lab and blood bank into an industrial holding, between the mid 1950s and the mid 1970s. On the productive side: lack of productivity; accumulation of stocks for lack of coordination between production and the commercial network of sales agents; expenses and costs to train technical staff in labs and in the sales network; lack of security in the infrastructures (a fire in September 1967 in the lab of Chemistry); informal supply of machinery and other productive elements needed to maintain the buildings and organize the post-sales services. In the distribution side: lack of specialized and standardized training of the sales network; difficulties to plan sales abroad due to changes in regulatory framework (prohibition of blood exports in 1965, regulation of prices by the Spanish Ministry of Health in the 1970s-90s); lack of internal statistics of sales to coordinate with production departments and avoid accumulation of stocks. In management, disorganized sales network and lack of experience in coordinating production departments and sales network. ${ }^{24}$ The external context of rampant inflation of the country during the $1970 \mathrm{~s}$ increased expenses in human resources, raw materials, services, and reduced profit 
margins of the sales. Some products had constant losses but were maintained to preserve reputation and avoid losing clients. The excellent evolution of the sales were, therefore, not a good simple indicator of what was going inside the company in these years of growth. ${ }^{25}$

The solution came with scale and scope following US models of factories. The Grifols family decided to build a brand new US style factory in Parets del Vallés (land was bought in 1966, factory built in 1970) with plenty of space to create a large standardized building that followed all the requirements of the US Food and Drug Administration in order to be an acceptable production center whose products could one day be registered in the US market, to compete with US corporations. It was an ambitious dream, and it would be American Hospital Supply Corporation, where Dade Reagents merged in the mid 1960s, a pioneering company in hospital equipment that would helped them with an alliance. From the mid 1960s until the mid 1980s AHS Corp. was to be not just a commercial partner for the Grifols firms, but also a business school of good practices in the health industries in order to learn how the best corporations produced and sold in the US and the global markets. AHS staff would greatly help in the planning, design, construction, and lay-out of the new building. Several trips to the different centers of AHS in the United States followed: to Miami in 1961 by Victor Grifols Lucas, Victor Grifols Roura in 1974 and other technical managers travelled in 1978 to Miami, Houston, Chicago, Evanston, Philadelphia, and Washington. ${ }^{26}$ The partnership with AHS allowed the Grifols company to learn new lay-outs, new financial and technical practices, and establish contacts with relevant authorities, like the Secretary of Health Mr. O`Keffe in March 1978. Sales and profits multiplied as well. Profits rose in 1975 from 7.3 million euros to 286 million euros in 1986, the golden age of the partnership of Grifols with AHS Corp. Americans had helped the Spaniards to acquire the strategic resources in terms of 
creation, and the management, of a large corporation in the health industries, and also much needed long-term stable capital that the Grifols needed to overcome the serious weaknesses the lab had had during the 1950s and 1960s.

A new generation participated in the new times. Victor Grifols Roura had joined in 1973 the company in the commercial department, and learnt very closely from AHS, and from his father and technical staff, how to run the US style Parets factory. He had been travelling to the United States and supervised the launch of the internationalization of the company, with the establishment of exports with China in 1983-1985, the first subsidiaries in Portugal in 1988, and in Argentina, Chile and Mexico in the early 1990s. He was well acquainted with the problems of the global health industries, and was trained in business administration in high quality local institutions. Grifols Roura, as the internal bulletins testify, was a tough manager who stubbornly wanted to impose the highest standards of quality and professionalism in all levels of the group, in close coordination with the North American, Japanese, and Spanish shareholders and staff. When he entered the Board with all the responsibilities formerly held by his father, in December of 1985 , he was well prepared to use the accumulated resources and know how to study what would be, with Alpha Therapeutic Corporation until the late 1990s, and afterwards with a diversity of long-term investors at home and abroad, a period of spectacular acquisitions in Europe, Asia, and above all the United States. ${ }^{27}$

Like Grifols, Ferrer had its beginnings in the industrial and scientific milieu of early $20^{\text {th }}$-century Barcelona and was strongly influenced by the talents, background and social networks of its founders and managers, basing its growth on alliances with leading international companies. The company's origins in the commercialization of imported chemical and pharmaceutical products would determine the focus and capabilities of Ferrer. The Ferrer family had seized control of Medir, Ferrer y Cía SRC at the death of 
their senior partner, and created two new companies, Manuel y Francisco Ferrer SL (1940) and Laboratorios Ferrer SL (1953), to take advantage of post-war Spain's nationalistic industrial policy. By then the second generation, second cousins Carlos Ferrer Salat and Jordi Ferrer Batlles, a chemical engineer and a pharmacist respectively, took over. The company continued to manufacture under foreign licenses and to represent foreign multinationals, but it also diversified into the food industry. ${ }^{28}$ Since the $1960 \mathrm{~s}$ Ferrer Salat became deeply involved in the modernization of the Spanish economy, playing a major role in the democratization of Spanish employers' associations, and lobbying for Spain's full integration into Europe and the dissemination of free market economics and social dialogue in post-Franco Spain. ${ }^{29}$

The growth and internationalization of Ferrer would be nurtured by this context. The most decisive change took place in the 1970s. ${ }^{30}$ Jordi Ferrer sold his share of the company (40\%). Lacking sufficient purchasing power himself, Ferrer Salat turned to another cousin, the financier Josep Vilarasau, to the new local industrial banks (Banco Industrial de Cataluña, founded in 1968, and Banco Catalan de Desarrollo, founded in 1964), and to a few private investors, all of them connected with Ferrer Salat's institutional initiatives. This type of investment network had been common in Catalonia since the beginning of industrialization.

In 1974, Ferrer Salat asked Rafael Foguet to replace him as CEO. Foguet was a chemist whose entire career had been spent with a leading Spanish chemical group Cros. His experience at Cros had been highly formative: in the building of an industrial group and in the lessons he learned from Cros' sinternational partners Hoechst, Wacker Chemie, Occidental-Hooker, Standard Oil, Shell, ICI, Dupont and Progil. ${ }^{31}$ German and NorthAmerican know-how of organization and international operations. As in Grifols, these partners transferred much more than products, they transferred manageurial and 
organizational models of production, commercialization typical of large pioneering corporations in knowledge-intensive industries.

At Cros Foguet had relentlessly promoted the diversification characteristic of industrial groups through the acquisition of firms working in more technologically advanced fields and the establishment of three research centers. Foguet demanded abundant financial resources and a hierarchical organization. It was no easy task. Foguet found himself saddled with a family-run firm that was still digesting the recent acquisition of another family-run firm, Robert, and "a daring mini-presence abroad" in three countries: Peru and Mexico, where Ferrer had established subsidiaries (dedicated mainly to product packaging under the brand name Novag) in 1961 and 1967, respectively; and Germany, where Ferrer had just acquired the pharmaceutical laboratory Trommsdorff. ${ }^{32}$ In terms of research, Ferrer had little more than "a laboratory of incremental R\&D that had achieved some recognition for producing esters and salts that improved the therapeutic properties of certain active ingredients" ${ }^{33}$

As in the case of Grifols, to transform Ferrer into an industrial group and promote innovation, required to exploit synergies and modernize the company's laboratories and production facilities. ${ }^{34}$ The new CEO replaced the existing structure, very informal, by a pyramidal and centralized model, with himself in control of the financial, human resources and research areas and periodic meetings with the department heads. The new structure required a legal change (incorporation), a new name (Ferrer Internacional) and the long-term objective of consolidation, something that would not be achieved until 1996. Between 1975 and 1996, Ferrer Internacional experienced exponential growth based on new products of chemical and pharmaceutical research, developed individually or jointly; new process and product technology; the adaptation of products to international norms; advances in safety and environmental issues; internationalization; diversification 
of activities into similar or complementary areas; and the training of management staff by area. In 1978 Ferrer had become a group in technical, legal and administrative terms. And it was clear that innovation was subordinated to commercialization. Diversification would involve the acquisition of companies working in fine chemistry, diagnostics, food products, dermopharmacy, nutriceuticals, and specialties. New activities such as food, aromas and diagnostics required their own facilities and development laboratories, as well as specific methods of production, control and distribution. Diversification reached the research area, which was structured into six specific R\&D centers, five of them in the Barcelona area.

Acquisitions provided organizational knowledge for the renewal of the production facilities, and the management organization, but also commercial platforms of global markets, as in Grifols. The purchase of Trommsdorff by Ferrer was a great opportunity identified by Ferrer Salat during one of his many international trips. Founded in 1795 in Erfurt and rebuilt in Aachen after the Second World War, Trommsdorff was a small yet highly respected company. In 1970 Trommsdorff was controlled by the Fossen and Hüllen families, who were coping with falling sales (from 20 million to 3-4 million DM) due to the recent discovery of negative side effects in its leading product, the stomach protector Rabro. Ferrer Salat purchased 50 per cent of Trommsdorff in exchange for 20 per cent of Ferrer. As Trommsdorff's financial situation continued to worsen, Ferrer, al ready an active board member, set the stage for Ferrer's 100 per cent acquisition of the German firm. In less than a decade, Ferrer had engaged in a dual path of internationalization. According to Foguet, Ferrer aimed to integrate Trommsdorff into the group's new structure as a means of achieving international ization in markets which were more demanding, but also more stable, than those of Latin America. 
As with Grifols, Spain's poor international reputation and country image posed a problem. The company decided to "hide" their Spanish background behind a German brand, but hired Spanish managers at Trommsdorff. Trommsdorff experienced a remarkable growth, doubling its staff to around 250 and increasing its productivity to twice that of Ferrer's Barcelona facilities. The German subsidiary became focused on four therapeutic areas: cardiovascular, anti-bacterial, dermatological and pneumological. Although Trommsdorff's research center was small and more oriented toward development than research, Ferrer sought from the very beginning to widen its activities by establishing collaborations with German research centers.

As in the case of Grifols'early exposure to German and US markets, Ferrer's early exposure to the German market provided valuable lessons for the international expansion over the next four decades. ${ }^{35}$ Ferrer, like Grifols, learnt that advanced markets required to deal with regulatory, technical and commercial issues; that they might be difficult to enter, but a safer bet in the long run. Further they learnt that industrial subsidiaries in countries such as Germany benefitted from both their industrial tradition and the prestige of the country, which provided an export platform. Finally, as in Grifols, Ferrer realized that to maintain a uniform group strategy, foreign subsidiaries must be effectively controlled through the group CEO and the director of the international division. This is the model that Ferrer tried to implement in the over twenty international subsidiaries established before 1996. Having a German laboratory in the heart of Europe did allow Ferrer to create commercial subsidiaries all over the continent (Greece, Italy, Portugal, Belgium and Ireland), to gain access to the Austrian market, to establish a subsidiary in Hong-Kong and, most crucially, to gain knowledge about advanced markets and acquire a solid global vision. 
Concerted research, still unusual in Spain in the 1970s, replaced the traditional scheme of a sovereign researcher that had characterized Ferrer since the 1950s. ${ }^{36}$ In addition, the new research center, staffed by circa 50 people, half of them university graduates, was kept separate from the factory and managed through a system of weekly meetings with the CEO and reports from each department of Ferrer Internacional. Foguet quickly sought to establish enduring relations with Spain's public and private research institutions and, in 1982, with the Massachusetts Institute of Technology (MIT) ${ }^{37}$ A medical doctor by training, Dr. Ortiz had worked for Sandoz and Hobson and Infar Natterman and helped design Spain's new regulatory framework before joi ning Ferrer. ${ }^{38}$

Over the next three decades, the size of the research center tripled. Most projects would be conducted in cooperation with researchers specialized in clinical pharmacology or with hospitals to test particular drugs before obtaining their official medical registration. ${ }^{39}$ A familiarization with foreign systems of research and registration did facilitate internationalization in all of its dimensions (licensing in and out). The hierarchical organizational model implemented in 1975 included "a precise, dynamic system of follow-up, with objective parameters and indicators and controlled by the company's decision-makers". ${ }^{40}$ Finally, since 1984 the Ferrer Research Foundation and the Severo Ochoa Award for Biomedical Research have helped to give visibility to Ferrer inside and outside Spain. ${ }^{41}$

In both cases, the early imprinting of knowledge obtained in the first stage was maintained in the second stage of growth, but changed the scale and scope between the 1930s and 1990s. The growth of national and international demand of health care products required, in both, to adapt to difficulties stemming from common institutional changes and the existence of foreign giants whose products were massively sold in the Spanish market. Both firms could have disappeared, as many other small labs, in this second stage 
of development of their businesses, in front of the difficulties, but both labs had managers and owners who foresaw a possible option: alliance with foreign giants, instead of just surviving in increasingly smaller market niches in the national market. Their dialogue with German and US leaders interested in entering the Spanish market was negotiated in such a way that both labs used it to improve capabilities and competitiveness in their organization, their structure, and their strategies. They learnt from the world giants, to become giants at home and slowly abroad in neighboring markets like Portugal or France. This stage was, therefore, a period where the early imprinting of the previous period was carried out to a more grown up mature stage.

Diverse pathways of expansion in developed markets after the 1990s: Mergers and Adquisitions (Grifols) and Strategic Alliances (Ferrer)

After the 1990s, Grifols and Ferrer were as many other labs able to grow by a race of new possibilities to buy abroad. It was a period of frenzy in mergers and acquisitions, which privileged investments in advanced markets in Western Europe and the United States.

From the 1990s Grifols' goal has been to integrate backwards and forward at global scale, by controlling the global supply of their raw materials (high quality plasma proteins), and in this way the most dynamic and profitable global markets in their market niche (plasma protein derivatives). With this strategy in mind, Grifols accelerated acquisitions in the United States in the early decades of the $20^{\text {th }}$ century. ${ }^{42}$ The alliance with the Green Cross Corporation, the Japanese leader in plasma products, and with Alpha Therapeutic Corporation (GCC's North American subsidiary) provided technological basis that increased sales in foreign markets to 25 per cent of total income, and exports multiplying by four since 1992 . The subsidiaries provided further experience in international accounts, payments, 
and the export of health and pharmaceutical products: Portugal was the first one in 1988, in the Czech Republic in 1990, Slovakia 1999, the Miami Pexaco Intl Corp to distribute to Central and South America (except Brazil until 1998) in 1990, Chile in 1990, Argentina 1991, Mexico in 1993, Brazil in 1998. A qualitative step forward came with the opportunity to buy ATC's subsidiaries in Germany, Italy and the United Kingdom in the mid 1997: safety problems had collapsed the financial future of these subsidiaries, and the Japanese GCC offered Grifols the option of purchase of their subsidiaries in these markets previously closed to Grifols by Alpha's commercial interests in Europe. The subsidiary in France came in 1999, and in 2003 the acquisition of Alpha's assets in the United States made Grifols establish headquarters in the US in Los Angeles where Alpha had had central offices and plants. The Singapore office opened in 2000, and the acquisition of Alpha's assets in 2003 led to merging with Singapore the subsidiaries in Malaysia, and Thailand, serving 15 countries in Asia. In 2001 Grupo Santander Central His pano became shareholder of Grifols in order to help buy Seracare, a leading plasma supplier in the United States, in 2002. It was the first step in acquisitions of companies that had donation centers in the United States, to integrate horizontally -and control the quality- of plasma in their manufacturing plants. The family Grifols retained 30 per cent, and the corporation became listed in the Spanish stock exchange in 2006. Three investments funds led by Morgan Stanley replaced Banco Santander Central Hispano and Deutsch Bank as main financial partners, in 2005. The third international expansion started with subsidiaries in Japan in 2006, in 2009 in China and Switzerland, and in the Nordic countries and Colombia in 2010. The core acquisitions after this year have concentrated in the US market with Talecris and assets from Novartis Diagnostics 
in 2011 and $2014 .{ }^{43}$ Today the most important market, and manufacturing plants, of the corporation are in the United States, and only 6 percent of sales go to the Spanish market. Grifols has more than 70 per cent of its employees in the United States, where it has totalled investments for 6,400 million euros (acquisitions and expansion of current installations combined), and of the 3,935 million euros in sales in 2015 more than 60 per cent were obtained in the North American market. ${ }^{44}$

In the case of Ferrer, the group consolidated accounts and organization in 1996, but maintained ownership and management under the Ferrer family, with a clear strategy of increasing their international presence in leading advanced markets. Their preference was Western Europe, in contrast with Grifols'dominant strategy of acquisitions in the United States. After Carles Ferrer Sal at's sudden death in 1998, his son Sergi took over. Two years later, Dr. Ortiz was succeeded by Dr. Joan Fanés as R\&D director. As for Rafael Foguet, he maintained his central role until 2004, being replaced by Dr. Jordi Ramentol. Forty years after its sound transformation, Ferrer is still a chemical, pharmaceutical and food product group which is vertically integrated, highly diversified and strongly commercial (licencing in and out), but with a more centered R\&D strategy and a more selective and stable system of alliances. To understand the group's growth strategy one has to pay special attention to Ferrer's four major partners as of 2015: Centro Nacional de Investigaciones Cardiovasculares (CNIC), Alexza, Histocell and Janus Developments. ${ }^{45}$ Alexza is an American pharmaceutical company specializing in research, development and commercialization of innovative products to treat acute and intermittent disorders such as asthma or schizophrenia. This alliance allows Ferrer participate in the development and marketing of Staccato and Adasuve systems, owned by Alexza. As for Histocell, it is a Spanish biopharmaceutical company developing cell therapy and tissue engineering products for regenerative medicine ${ }^{46}$ This alliance has two ongoing projects. 
The first project, aimed at developing a new cell therapy medication for the treatment of traumatic spinal cord injuries, marks a completely new strategy for the use of adult stem cells. The second focuses on the development of a new drug from the patient' sadult stem cells and a new biomaterial for clinical application in articular cartilage injuries. Janus Developments is an incubator for biotech start-ups that facilitates collaboration between academic research, industry and investors, created in 2009 with the support of Ferrer, Enantia and Caixa Manresa. ${ }^{47}$ Finally, in September 2016 Ferrer has launched an alliance with the public research center IBEC and the private company Mind the Byte, both based in Barcelona, devoted to the computational development of therapeutic molecules to fight cancer metastasis.

Grifols and Ferrer Internacional remain deeply rooted in the biomedical and chemical-pharmaceutical cluster of Barcelona, with slight differences. Grifols has strong connections with the research centers of the city, but has concentrated most of his scientific staff outside Spain due to their mergers and acquisitions in Europe, America, and Asia and the concentration of donor centers and clients in the United States. On the other side, Ferrer has a strong marketing and commercial component located in Barcelona, and shows a very high percentage of its team trained in Catalan universities. Ferrer preferably resorts to Spanish scientists to form scientific committees. Today Ferrer's international network, with 27 subsidiaries, is one of the most extensive of Spanish-funded laboratories, even though Ferrer has only two industrial subsidiaries: Mexico and Alsdorf. Their function is strictly instrumental: to provide support to and increase European and American sales of products which are developed in Barcelona. This is coherent with the company's historical trajectory and with the fact that sales are concentrated in Europe (66\%) and Latin America (21\%). Ferrer's international sales account for nearly $50 \%$ of the group's total sales. The R\&D activity of the foreign 
subsidiaries is very modest. However early and daring, Ferrer's internationalization remains essentially commercial in nature and, much as it was in the 1970s, a drive to widen markets in order to sustain innovation, which takes place in Barcelona. In Grifols, with 96 per cent of its sales outside Spain, and sales and employment concentrated in the United States, the R\&D of foreign subsidiaries is strategic and are concentrated in or around its extensive network of donor centers in the United States, and the connected factories. Grifols internationalization is essentially productive in nature, in search of very stable and large high quality markets of raw materials derived from human plasma.

Both companies started small, but grew large in many ways because of their early ties with leading giants from Germany and the United States. The small companies from a backward country specialized in an industry which required initially high quality knowledge and networks. Both firms accumulated this initial knowledge at home in the Barcelona cluster of biomedical scientists born in the late $19^{\text {th }}$ century. Both firms were able to grow, following Chandler's chronology, after the 1930s, but for different reasons to those posited by Chandler. Not by establishing barriers to competitors, but by establishing networks and alliances with enormous giants who did not see the Spanish labs as a threat, but as a target. Once the alliance yielded results, in terms of scale and scope and internationalization via foreign trade, the Spanish companies used organizational knowledge from those giants to launch, in a favourable period after the 1990s, their foreign direct investment into the US or Germany, where old labs were being sold, or near bankruptcy. In this way, after a century of learning from giants, the small firms joined the reduced group of giants in their industry, and started to try to establish, as Chandler indicated, entry barriers for other potential followers. 


\section{Lessons from History. Final Remarks}

The comparative study of Grifols and Ferrer shows that the oligopolistic structure of the modern pharmaceutical industry did not stop firms based in late industrialized countries from developing their own organizational and innovation capabilities throughout the $20^{\text {th }}$ century and going global since the 1990s. Personal and institutional networks played a crucial role in the long and effective learning strategies of both multinationals. And early international imprinting from advanced countries accelerated the formation of specific, combinative capabilities.

Six conclusions emerge from our comparative exercise. First, both Grifols and Ferrer established early contacts with incumbents from more developed countries, contacts which provided knowledge, networks, and entrepreneurial attitudes oriented to embed innovative strategies and structures in their small companies in the early $20^{\text {th }}$ century. The Grifols travelled, studied or worked in German clinical labs in the first three decades of the twentieth century, keeping in touch in those early years with the most modern techniques to organize clinical labs for diagnosis that will develop in the world after World War II. Ferrer's internationalization in pharmaceutical products started a close link with German markets, also learning German organizational routines in the pharmaceutical industry in the 1960s. In both companies import activities and distribution of products of corporations from developed economies, leaders in innovation, contributed to their learning and training with international players. A great share of the profits of Grifols and Ferrer since the 1950s until the 1970s came from the import and distribution in Spain of specialties from advanced countries, a crucial activity to achieve and sustain international competitiveness over time.

Second, in both companies leading scientists of the founding family 
institutionalized innovative scientific routines in their companies before the 1970s, and in both companies a change took place after the 1970s when professional managers with a German and/or American background occupied CEO positions and led an accelerated era of foreign investments and exports: Victor Grifols Roura in Grifols and Rafael Foguet in Ferrer.

Third, both corporations made this transition from a science-managed firm to a business-oriented global corporation with culturally hybrid entrepreneurs and managers. ${ }^{48}$ Culturally-hybrid entrepreneurs and managers possessed a rare, valuable intangible experience: they had successful command of how to combine organizational knowledge of late developed markets, with organizational knowledge of developed markets. In Grifols there were several family members with this intangible asset difficult to find in Spain before the 1980s (the founder, the sons, and the grandsons) and members of their social network (the Cuban-American Guillermo Anido innovation manager in the US Dade Reagents and American Hospital Supply Corp, and Hikosuke Yorihiro, the Japanese C.E.O. of Alpha Therapeutic Corporation). In Ferrer, the founder Ferrer and Rafael Foguet. Grifols accumulated these networks and knowledge through travels, scientific congresses, and import activities with France and Germany before the 1940s, the United Kingdom in the second half of the 1940s, and above all with the US since the 1950s, and U.S. and Japan after the 1980s.

Fourth, the stage of development in which the transformation of a small lab into a vertically integrated industrial group took place had profound and lasting effects on corporate development and R\&D. It is important to underline the relationship between internationalization and innovation, with the former always serving the latter in the two cases. The long training received by Grifols during their alliances and joint-ventures 
with three North American corporations between the late 1950s and 1998 was essential to understand their self-confidence and their speed in mergers and acquisitions in the world after the 1990s. Similarly, Ferrer's history of enduring strong embeddedness in the Barcelona biomedical cluster was and remains the key of their international competitiveness.

Fifth, investments in Europe, in the 1970s by Ferrer and the 1980s-90s by Grifols, provided the two companies with organizational knowledge about international operations, a fundamental resource to increase industrial, commercial, and regulatory capabilities within and outside Europe. Trommsdorff's acquisition served well the objective of allowing a modest Spanish pharmaceutical firm to access mature markets and increase its industrial, commercial and regulatory capabilities. Grifols's acquisition of the European subsidiaries of the North American Alpha Therapeutic Corporation transformed a Spanish-based company into a European corporation that became visible as a new global player in the plasma industry after the 1990s.

Sixth, private family ownership have not prevented Grifols and Ferrer from going international and innovating. Self-financing and strategic alliances have always played a major role in both since the mid twentieth century, but Grifols resorted to the local bank Sabadell in the 1970s-1980s and to a variety of other Spanish and international banks, the stock market and international investors since the 1990s. In contrast, Ferrer, which remains a closely held group, resorted to three related local banks to fund its ambitious growth plans.

And finally, the accumulation of social networks useful to expand the market niche of the two case studies must be underlined to understand the long-term resilience of the two healthcare companies. Both companies were founded by Catalan 
entrepreneurs very connected to centers of scientific excellence at the local and international level since their early beginnings until today. Both created enduring social networks within their different market niches, without which the transformation of small labs into global corporations could not have taken place. Grifols accumulated throughout the 20th century close networks with the local and global scientific community in their two market niches. Ferrer led and participated actively in the creation of networks with the local and European elites. In both cases the leadership in the creation and participation of networks helped them to participate in the design of strategic rules of the game in the Spanish pharmaceutical industry in the case of Ferrer, and in the global plasma industry in the case of Grifols.

Early exposure to advanced markets helped them grow outside, but in dialogue with, the oligopolistic structure of the world healthcare industry. It shows further that the specific capabilities developed by both firms were determined first of all by personal and institutional networks that linked them to advanced research centers since the 1920 s. And, second, by their acquisitions, mergers, and strategic alliances, that gave them access to advanced organizational and global commercial knowledge from leading German and American companies since the 1960s.

\section{Notes}

1 Galambos and Sewell, Networks of Innovation, pp; Galambos and Sturchio, "Pharmaceutical Firms," pp; Vagelos and Galambos, Medicine, Science, and Merck; and Chandler, Shaping the Industrial Century.

2 Data from public health care corporations listed in Nasdaq, one the leading world markets for these industries, show that at the end of 2016 the largest major pharmaceutical corporation in the US (Johnson and Johnson) has a market capitalization which is six times the capitalization of the next follower (Abbott Laboratories) in this subsector of the 
health care industries, see http://www.nasdaq.com/screening/companies-byindustry.aspx?industry=Health\%20Care\&marketcap=Mega-cap\#ixzz4TN36thM5Na

3 Guillén and García-Canal, "American model of the multinational"

4 Campins and Pfeiffer, "La importancia de las redes sociales" for the Argentinian pharmaceutical industry, and Fernández Pérez, "Andrómaco" for the case study of the US subsidiary of the Spanish pharmaceutical multinational Andrómaco between 1928 and 1946.

5 CGCOM, Informe sobre el sector farmacéutico, pp; OECD, Statistics 2016.

6 Prados de la Escosura, "World Human Development"

7 Guillen and García-Canal (2007) "La expansion internacional”. For the purposes of this research, the original database has been updated until 2014, following the same methodology of search and codification.

8 We considered advanced countries those hosting the headquarters of the world leading firms in the industry; namely U.S., U.K., France, Germany, Switzerland, and Japan.

9 See note 5 above.

10 Sjögren, "Family Capitalism"; Puig, "The Global Accommodati on"; Puig, "Networks of Opportunity"; Chauveau, "Quelle Historie de l'hôpital"; Colli, "Patterns of Innovation"; Zamagni, "The Rise and Fall"; and Donzé, "Si emens and the Construction"

${ }^{11}$ Estadística del comercio exterior de España. Madrid, Dirección General de Aduanas/Ministerio de Hacienda 1905 to 1980, and Ministerio de Economía y Competitividad for 2005.

12 Pérez Moreda, Reher and Sanz, La Conquista de la Salud

13 Rodríguez and Martínez, Salud Pública en España

14 Hochadel and Nieto-Galán.

15 Sabaté,2015; Zarzoso and Martínez-Vidal 2016; Fernández Pérez, "Laboratorios Andrómaco"; and Fernández Pérez 2017.

16 Cabana, Carles Ferrer Salat

17 "Spain had a poor reputation in the world and it was al most impossible to sell anything abroad... we began to sell plasma to a German lab, but under its own brand" (Grifols i Lucas 2009:110).

18 Historical Archive Museu Grifols. Private correspondence and Notarial Records 19571966.

19 Historical Archive Museu Grifols. Agreement with American Hospital Supply Corporation. And Grifols 2011:113. On Antonio Ruiz and these three women, Grifols 2011.

20 Historical Archive Museu Grifols. Private correspondence and Commercial Agreements. 1946-1998.

21 Historical Archive Museu Grifols in Barcelona. Ref. 06316

22 Historical Archive Museu Grifols in Barcelona. Ref. 06316

23 Historical Archive Grifols in Sant Cugat del Vallés. Ref 05878c and 05878b

24 Historical Archive Museu Grifols in Barcelona. Ref. 2176 Actas Laboratorio Grifols Caja 9215 June 1965 Junta General ordinaria de accionistas, and Juntas for 15 June 1966, 20 June 1967, 7 June 1968, 5 June 1974, 7 June 1968, 18 june 1973.

25 Historical Archive Museu Grifols. Ref 2176. Actas Laboratorio Grifols 1965-87.

26 Historical Archive Museu Grifols in Barcelona. Ref 05626 and Conference in Miami (1994) and Boletín Informativo Grupo Grifols May 1980 in Ref 05659.

27 Victor Grifols Roura, interviewed 13 February 2015.

28 Cercle d'Economia, Cercle d'Economia 1958-1983; Maluquer de Motes, El Largo Camino a Europa 
29 See note 4 above, and Ferrer Salat, "Europa y España"

30 Ferrer Sal at, "Hacia una Política Industrial"

31 Foguet, Solemne discurso de investidura

32 Bank of Spain, Historical Archive, Deed of Conversion, 1975.

33 See note 31 above, 128.

34 See note 31 above, 128-129.

35 See note 31 above, 138-139.

36 Foguet, "Investigación concertada"

37 See note 31 above, 134-135.

38http://www.jaortiz.info/index.html, accessed July 2016.

39 Historical Archive of the Bank of Spain, IEME Files, Deed of Conversion, 1975.

40 See note 31 above, 135.

41 http://www.ferrer.com, accessed July 2016.

42 Acquisitions of Grifols in the US: http://www.grifols.com/portal/es/grifols/origens http://www.belinked.es/exito(March2015);http://openaccess.uoc.edu/webapps/o2/bitstr eam/10609/13101/1/GRIFOLS\%20Factores\%20Competitividad\%20a\%20Largo\%20P lazo.pdf(March 2015); http://www.elexportador.com/062003/digital/empresas huellas.asp (about the Probitas operation, March 2015).

43 Grifols, Historical Archive Grifols in Barcelona. Revista Cosmos; www.grifols.com.

44 Grifols, www.grifols.com and La Vanguardia, Saturday 9 July 2016.

45 www.Ferrer.com, accessed September 2015.

46 www.histocell.com, accessed May 2016.

47 www.spheriumbiomed.com, accessed May 2016.

48 Fernández Pérez, "Acerinox"

\section{References}

Cabana, F. Carles Ferrer Salat. Biografía. Barcelona: RBA, 2015.

Campins, M. and A. Pfeiffer, "La importancia de las redes social es en los orígenes de la industria farmacéutica argentina. El caso de los catalanes en Argentina", Revista de Historia Industrial, 47 (2011): 17-50.

Cercle d'Economia. Cercle d'Economia 1958-1983. Una trajectòria de modernització $i$ convivencia. Barcelona: Cercle d'Economia, 1983.

CGCOM (Consejo General de Colegios Oficiales de Médicos de España)/ OMC (Organización Médica Colegial). Informe sobre el sector farmacéutico. Madrid: CGCOM, 2014. www.cgcom.es

Chandler, A.D. Shaping the Industrial Century: The Remarkable Story of the Evolution of the Modern Chemical and Pharmaceutical Industries. Cambridge, MA: Harvard University Press, 2005. 
Chaqués, L. "Políticas públicas y democracia en España. La política farmacéutica del franquismo a la democracia. Unpublished doctoral dissertation, Universitat de Barcelona, 1999.

Chauveau, S. "Quelle histoire de l'hôpital aux XX"e et XXI siècles ?' Les Tribunes de la santé 4, no. 33 (2011) : 81-89.

Colli, A. "Patterns of Innovation, Strategies and Structures in the Italian Chemical Industry, 1973-2003." In Innovation and Entrepreneurial Networks in Europe, edited by P. Fernández Pérez and M.B. Rose, 99-117. New York: Routledge, 2010.

Donzé, P.-Y. "Siemens and the Construction of Hospitals in Latin America 1949-1964." Business History Review 89, no. 3 (2015): 475-502.

Fernández Pérez, Paloma, and Andrea Colli, eds. The Endurance of Family Businesses. A Global Overview. Cambridge: Cambridge University Press, 2013.

Fernández Pérez, Paloma and Andrea Lluch, eds. Evolution of Family Businesses. Continuity and Change in Latin America and Spain. U.K.: Edward Elgar Publishers, 2016. Original version in Spanish published in 2015 as Familias empresarias y grandes empresas familiares en América Latina y España. Bilbao: FBBVA.

Fernández Pérez, P., and N. Puig. "Dynasties and Associations in Entrepreneurship: An Approach through the Catalan Case." In The Determinants of Entrepreneurship: Leadership, Culture, Institutions, edited by J.L. García-Ruiz, and P. Toninelli, 105125. Pickering \& Chatto, 2010.

Fernández Pérez, P. “Acerinox. A Successful Japanese Joint-Venture in Southern Europe in the Second Half of the Twentieth Century." Entreprises et Sociétés, 80 (2015): 57-83.

Fernández Pérez, P. "Laboratorios Andrómaco. Origins of the first subsidiary of a Spanish pharmaceutical multinational in the United States (1928-1946)." Journal of Evolutionary Studies in Business 1, no. 2 (2016): 266-275.

Ferrer Salat, C. "Hacia una política industrial de integración." Información Comercial Española. (1971): 417-418.

Ferrer Sal at, C. "Europa y España: La lucha por la integración." Discurso de ingreso en la Real Academia de Ciencias Económicas y Financieras. Barcelona, 1993.

Foguet, R. "Investigación concertada en el campo de la química fina y farmacéutica." Boletín de la Sociedad Catalana de Ciencias Físicas, Químicas y Matemáticas. Barcelona, 1983.

Foguet, R. Solemne discurso de investidura Dr.H.C. Univesitat de Barcelona, 2010. 
Galambos, L., and J.E. Sewell. Networks of Innovation: Vaccine Development at Merck, Sharp\&Dohme and Mulford, 1895-1995. Cambridge: Cambridge University Press, 1995.

Galambos, L., and J.L. Sturchio. "Pharmaceutical Firms and the Transition to Biotechnology: A Study in Strategic Innovation.” Business History Review 72, no. 2 (1998): 250-278.

García-Canal, E., M. Guillén, and A. Valdés. "La internacionalización de la empresa española. Perspectivas empíricas.” Papeles de Economía Española 132 (2012): 64-81.

Grifols i Lucas, V. Amb un suro i un cordill. Vivències d'un empresari de postguerra. Barcelona: Grifols, 2009.

Grifols. When a Dream Come True. Grifols: Barcelona, 2015.

Guillén, M., and E. García-Canal. “La expansión internacional de la empresa española: una nueva base de datos sistemática." Información Comercial Española. Revista de Economía 839 (2007): 23-34.

Guillén, M. F., and E. García-Canal. "The American model of the multinational firm and the "new" multinationals from emerging economies." Academy of Management Perspectives 23, no. 2 (2009): 23-35.

Malerba, F., and L. Orsenigo. "The evolution of the pharmaceutical industry." Business History 57, no. 5 (2015): 664-687.

Maluquer de Motes, J. El largo camino a Europa. Cincuenta años del Círculo de Economía 1958-2008. Barcelona: Centro editor PDA, 2008.

Pérez Moreda, V., D. Reher, and A. Sanz. La conquista de la salud. Mortalidad y modernización en la España contemporánea. Madrid: Marcial Pons, 2015.

Pons, J. and M. Vilar El seguro de salud privado y público en España. Su análisis en perspectiva histórica. Zaragoza: PUZ, 2014.

Prados de la Escosura, L. "World Human Development 1870-2007." Review of Income and Wealth 61, no. 10 (2014): 220-247.

Puig, N. and S. López, "Chemmist Engineers and Entrepreneurs. The Chemical Institute of Sarria’s impact on Spanish Industry (1916-1922)", History and Technology, 11 (1994): 345-359.

Puig, N. "The global accommodation of a latecomer: The Spanish chemical industry since the petrochemical revolution." In The global chemical industry since the petrochemical revolution, edited by L. Galambos, T. Hikino, \& V. Zamagni, 368-400. Cambridge: CUP, 2006. 
Puig, N. "Networks of Opportunity and the Spanish Pharmaceutical Industry." In Innovation and Entrepreneurial Networks in Europe, edited by P. Fernández \& M. Rose, 164-183. UK: Routledge, 2010.Rodríguez Ocaña, E., and F. Martínez Navarro. Salud pública en España. De la Edad Media al siglo XXI. Sevilla: Junta de Andalucía, 2008.

Sjögren, H. "Family Capitalism Within Big Business." Scandinavian Economic History Review 54, no. 2 (2006): 161-186.

Vagelos R., and L. Galambos. Medicine, Science, and Merck. Cambridge: Cambridge University Press, 2004.

Zamagni, V. "Therise and fall of the Italian chemical industry 1950-1990." In The global chemical industry in the age of petrochemical revolution, edited by L. Galambos, T. Hikino and V. Zamagni, 347-367. Cambridge: Cambridge University Press, 2006.

Archives

Museo Grifols, Barcelona. Historical Archive and Library.

Grifols Corporation, Sant Cugat del Vallés, Barcelona.

Archivo General de la Administración, Madrid.

Banco de España (Madrid). Historical Archive and Library.

Websites

http://www.ferrer.com, Access September 2015 and July 2016

www.grifols.com Access 2014, 2015 and 2016

http://www.jaortiz.info/index.html, Access July 2016

www.histocell.com, accessed May 2016

www.spheriumbiomed.com, accessed May 2016

Interviews

Eduardo Herrero, 9 December 2013.

Rosa Avella, interviewed 2013-2015.

Victor Grifols Roura, 13 February 2015.

Francesc Cabana, 11 November 2015.

Rafael Foguet, 14 December 2015. 